\title{
SELF-EFFICACY SISWA SD YANG MENGHADAPI SOAL CERITA MATEMATIKA: DAMPAK PENGAJARAN STRATEGI METAKOGNITIF IDEA
}

\author{
Natalia W. Darmawan ${ }^{1}$, Sri Tiatri ${ }^{2}$, Heni Mularsih ${ }^{3}$ \\ ${ }^{1}$ Fakultas Psikologi, Universitas Tarumanagara Jakarta \\ Email: nataliawulansaridarmawan@gmail.com \\ ${ }^{2}$ Fakultas Psikologi, Universitas Tarumanagara Jakarta \\ Email: sri.tiatri@untar.ac.id \\ ${ }^{3}$ Fakultas Psikologi, Universitas Tarumanagara Jakarta \\ Email: henim@mku.untar.ac.id
}

Masuk : 14-04-2019, revisi: 25-11-2019 diterima untuk diterbitkan : 26-11-2019

\begin{abstract}
ABSTRAK
Performa pemecahan soal cerita matematika pada siswa SD di Indonesia masih rendah. Salah satu faktor yang menyebabkan rendahnya performa pemecahan soal cerita matematika adalah self-efficacy rendah pada siswa. Untuk mengembangkan self-efficacy siswa diperlukan penguasaan strategi belajar yang efektif. Beberapa penelitian yang menguji keterkaitan antara strategi metakognitif dan pemecahan masalah matematika telah banyak dilakukan, namun di Indonesia menunjukkan hasil yang berbeda. Penelitian ini bertujuan melihat pengaruh pengajaran strategi metakognitif IDEA terhadap peningkatan self-efficacy soal cerita matematika pada siswa kelas 5 SD. Strategi metakognitif IDEA merupakan metode pengajaran soal cerita matematika yang dikembangkan berdasarkan teori Polya (1973) terdiri dari empat langkah, yaitu memahami masalah, membuat rencana perhitungan, melakukan perhitungan, dan melakukan pengecekan kembali. Self-efficacy pemecahan soal cerita matematika merupakan suatu keyakinan individu atas kemampuannya dalam mengatur diri dan menyelesaikan tugas pemecahan soal cerita matematika. Sampel dalam penelitian ini adalah siswa kelas 5 SD X Jakarta Barat berjumlah 6 siswa. Teknik pengambilan sampel dilakukan dengan purposive sampling. Pengukuran self-efficacy soal cerita matematika menggunakan kuesioner self-efficacy yang disusun berdasarkan teori Bandura (1997) meliputi dimensi level, generality, dan strength. Metode penelitian yang digunakan adalah metode kuantitatif, dengan desain penelitian quasi experiment, one group pretest-posttest. Analisis data dilakukan dengan menggunakan uji statistik paired sample T-test. Hasil penelitian menunjukkan bahwa tidak ada perbedaan yang signifikan pada self-efficacy pemecahan soal cerita matematika sebelum dan sesudah pengajaran strategi metakognitif $(\mathrm{t}=-1.535, \rho>0.05)$. Berdasarkan hasil analisis, disimpulkan bahwa tidak ada pengaruh pengajaran strategi metakognitif terhadap peningkatan self-efficacy soal cerita matematika pada siswa kelas 5 SD.
\end{abstract}

Kata Kunci: self-efficacy, pemecahan soal cerita matematika, pengajaran strategi metakognitif

\section{ABSTRACT}

Elementary school students in Indonesia still struggle to solve mathematical word problems. One factor that causes this is low self-efficacy among students. To develop self-efficacy, students need mastery of effective learning strategies. Several studies examining the link between metacognitive strategies and mathematical problem solving have been carried out, however in Indonesia they show varied results. This study aims to examine the effect of teaching IDEA metacognitive strategies on increasing self-efficacy of 5th grade students in doing mathematical word problems. IDEA metacognitive strategy is a method of teaching mathematical world problems developed based on Polya's (1973) theory consisting of four steps, namely understanding the problem, making a calculation plan, doing the calculation, and re-checking. Self-efficacy in solving mathematical word problems is an individual's belief in his/her ability to organize themselves and complete the task of solving mathematical word problems. The samples in this study were six $5^{\text {th }}$ grade students of SD X West Jakarta. The sampling technique is purposive sampling. Measurement of self-efficacy in solving mathematical word problems used a self-efficacy questionnaire that was compiled based on Bandura's (1997) theory which includes levels, generality, and strength dimensions. The research method is quantitative, with a quasi-experimental research design, one group pretest-posttest. Data analysis was performed using paired sample T-test statistical test. The result shows that there is no significant differences in the self-efficacy in solving mathematical word problems before and after teaching metacognitive strategies $(t=-1.535, \rho>0.05)$. Based on the results of the analysis, it was concluded that teaching metacognitive strategies has no effect on increasing self-efficacy in solving math word problems among 5th grade students.

Keywords: self-efficacy, solving mathematical word problems, teaching metacognitive strategy 


\section{PENDAHULUAN}

\section{Latar Belakang}

Matematika merupakan ilmu pengetahuan yang memegang peranan penting dalam berbagai bidang kehidupan. Namun dilihat dari kondisi realita pendidikan matematika di Indonesia dapat dikatakan memprihatinkan. Dalam survei yang dilakukan Programme for International Student Assessment (PISA) dari tahun 2003 hingga tahun 2012 Indonesia selalu berada di urutan tingkat bawah. Pada tahun 2003 Indonesia berada pada peringkat 38 dari 40 negara, tahun 2006 Indonesia berada pada peringkat 50 dari 57 negara, tahun 2009 Indonesia menempati peringkat 61 dari 65 negara, tahun 2012 Indonesia menempati peringkat 64 dari 65 negara (Satria, 2012), dan tahun 2015 menempati peringkat 63 dari 69 negara peserta dalam hal matematika (Iswadi, 2016).

Berdasarkan data UNESCO, mutu pendidikan matematika di Indonesia berada pada peringkat 34 dari 38 negara yang diamati. Data lain yang menunjukkan rendahnya prestasi matematika siswa Indonesia dapat dilihat dari hasil survei Pusat Statistik Internasional untuk Pendidikan (National Center for Education in Statistics, 2003) terhadap 41 negara dalam pembelajaran matematika, dimana Indonesia mendapatkan peringkat ke 39 di bawah Thailand dan Uruguay (Satria, 2012). Menurut Presiden Asosiasi Guru Matematika Indonesia (AGMI) Drs. Firman Syah Noor, M.Pd. (dalam Nurfuadah, 2013) buruknya prestasi matematika di tingkat dunia disebabkan kurikulum pendidikan matematika di Indonesia belum menekankan pada pemecahan masalah, melainkan pada hal-hal prosedural. Siswa dilatih menghafal rumus, tetapi kurang menguasai penerapannya dalam memecahkan suatu masalah. Selain itu, pola pendidikan matematika bernalar yang melatih siswa dalam memetakan dan memecahkan masalah tidak akan membuat siswa tertarik, karena orientasi mereka pada nilai UN dan kelulusan.

Pemecahan masalah atau yang dikenal dengan soal cerita matematika merupakan aktivitas kognitif kompleks yang melibatkan banyak proses (García, Rodríguez, Castro, Pienda, \& Torrance, 2016), seperti melibatkan pengetahuan tentang konstruksi semantik dan hubungan matematis, serta pengetahuan tentang keterampilan dan strategi numerik dasar (Lai., Zhu, Chen, \& Li, 2015). Pemecahan soal cerita matematika diajarkan kepada siswa dengan tujuan untuk mengembangkan kemampuan siswa menyelesaikan permasalahan dan menerapkan matematika dalam kehidupan sehari-hari (Gurat \& Medula, 2016).

Ciri-ciri siswa dengan performa pemecahan masalah matematika rendah juga terjadi pada siswa kelas 5 SD X, Jakarta Barat. Berdasarkan wawancara dengan salah satu guru wali kelas yang juga mengajar pelajaran matematika, sebanyak 15 siswa dari 27 siswa di dalam kelas mengalami kesulitan dalam soal cerita matematika dan mendapatkan nilai ulangan di bawah standar ketuntasan $(\leq 65)$. Sikap yang ditunjukkan siswa, antara lain melamun disertai tatapan kosong ketika guru menjelaskan tentang soal cerita matematika, dan tidak mampu menjawab pertanyaan yang ditanyakan guru secara lisan. Selain itu, ada juga sebagian murid yang tidak menjawab pertanyaan soal, mereka hanya menuliskan langkah-langkah menjawab: diketahui (to know), ditanya (to ask), dan jawab (to do) guna mendapatkan skor menulis saja. Perilaku ini terjadi berulang kali, hampir pada setiap topik materi yang diujikan. Siswa cenderung memilih untuk mengikuti remedial atau mengerjakan tugas tambahan (project) dari guru guna mendapatkan perbaikan nilai.

Kurikulum dalam mata pelajaran kelas 5 SD merupakan awal dari proses pembelajaran yang lebih banyak menekankan pada optimalisasi tugas kognitif kompleks. Tugas kognitif kompleks dalam kurikulum kelas 5 SD tampak pada isi materi semua mata pelajaran yang sudah mulai 
menekankan pada proses berpikir kritis, bernalar, dan pemahaman, termasuk pada pelajaran matematika dan bahasa (Kemendikbud, 2013). Kompleksitas tugas kognitif yang lebih tinggi ini dapat menjadi salah satu faktor rendahnya performa pemecahan soal cerita matematika pada siswa kelas 5 SD. Di samping faktor tersebut, self-efficacy yang rendah pada siswa juga dapat menjadi salah satu penyebab rendahnya performa pemecahan masalah matematika. Coutinho dan Neuman (2008) menyatakan bahwa self-efficacy merupakan prediktor dari performa dan prestasi akademik. Penelitian yang dilakukan oleh Pajares (2008), Schunk dan Ertmer (2000), dan Zimmerman (2002), mengungkapkan bahwa keyakinan self-efficacy memengaruhi prestasi akademik siswa di samping pengetahuan dan keterampilan yang dimiliki sebelumnya.

Self-efficacy rendah yang dibiarkan pada siswa akan berdampak negatif pada prestasi belajar siswa (Pajares \& Miller, 1994). Siswa yang memiliki self-efficacy rendah dalam bidang matematika cenderung mendapatkan nilai ulangan rendah, menganggap matematika sebagai ancaman (Putwain \& Symes, 2014), dan mengalami kecemasan dalam bidang matematika (Akin \& Kurbanoglu, 2011; Kvedere, 2014; Jameson \& Fusco, 2014). Selain itu, self-efficacy rendah pada siswa juga dapat berakibat dalam kesulitan mengambil keputusan karir, maupun keputusan non-karir di masa mendatang (Lopez \& Lent, 1992; Paulsen \& Betz, 2004; Hepler \& Feltz, 2012; Kvedere, 2014).

Untuk mengembangkan kemampuan dan self-efficacy dalam bidang soal cerita matematika, siswa harus memiliki penguasaan strategi belajar yang membuat mereka mandiri dalam kemajuan belajar mereka (Schunk \& Rice, 1991). Self-efficacy menjadi salah satu faktor yang berpengaruh pada kemampuan siswa untuk mengatur dirinya dalam belajar, sehingga berdampak pada orientasi tujuan serta pilihan strategi yang digunakan oleh siswa dalam memecahkan masalah matematika (Hoffman \& Spatariu, 2008). Para peneliti menegaskan bahwa self-efficacy yang tinggi berasosiasi dengan metakognisi yang lebih tinggi, termasuk dalam penggunaan strategi pemecahan masalah yang lebih efisien, serta ketahanan dalam menghadapi tantangan (Pajares, 2005).

Salah satu strategi belajar yang dapat digunakan untuk mengaktifkan keterampilan kognitif dalam pemecahan masalah matematika adalah strategi metakognitif. Metakognitif mengacu pada komponen kognitif dari regulasi diri yang bertanggung jawab terhadap proses kesadaran akan pemecahan masalah, proses pemantauan, dan mengontrol proses mental individu (García et al., 2016). Metakognitif dalam pemecahan soal cerita matematika menyangkut keyakinan tentang kesadaran pikiran dalam mengerjakan soal matematika dan proses pemantauan (Cornoldi, Carretti, Drusi, \& Tencati, 2015). Menurut Zimmerman (2002) dan Montague (2008), strategi metakognitif digunakan untuk memantau dan mengevaluasi perkembangan kognitif selama proses pengerjaan tugas berlangsung. Pengajaran strategi metakognitif sering digunakan untuk membantu siswa dalam memantau dan mengontrol efektifitas serta akurasi pemahaman dan pemecahan masalah yang mereka lakukan (Lin dalam Nelson, 2012).

Beberapa penelitian yang menguji keterkaitan antara strategi metakognitif dan pemecahan masalah matematika telah banyak dilakukan. Salah satunya penelitian yang dilakukan oleh Ozsoy dan Ataman (2009) yang menunjukkan bahwa strategi metakognitif memiliki pengaruh yang kuat dalam meningkatkan prestasi pemecahan masalah matematika siswa kelas lima. Penelitian yang dilakukan oleh Pennequin, Sorel, Nanty, dan Fontaine (2010) menunjukkan bahwa pelatihan metakognitif pada anak kelas tiga memberikan peningkatan dalam pemecahan masalah matematika. Penemuan lain menunjukkan adanya pengaruh yang besar dari metakognitif ketika diberikan kepada siswa kelas tujuh bersama dengan cooperative learning 
terhadap penyelesaian tugas matematika, baik masalah yang standar maupun sulit (Kramarski, Mevarech, \& Arami, 2002). Penelitian lain menunjukkan bahwa penggunaan strategi metakognitif, seperti self-explanation (Tajika, Nakatsu, Nozaki, Neumann, \& Maruno, 2007) dan strategi metakognitif CRIME (Careful Reading, Recall, Possible Strategies, Implement Possible Strategies, Monitor, Evaluation) yang dilakukan oleh Teong (2003), keduanya dapat meningkatkan kemampuan pemecahan masalah matematika yang tersaji dalam kata-kata pada anak usia sekolah dasar.

Beberapa penelitian di atas merupakan penelitian-penelitian yang dilakukan di luar Indonesia. Namun, penelitian di Indonesia menunjukkan hasil yang berbeda. Penelitian Cahyani (2008) tentang efektivitas pelatihan regulasi metakognisi untuk meningkatkan kemampuan memecahkan problem matematika pada siswa SMA kelas XI, menunjukkan tidak adanya pengaruh pelatihan regulasi metakognisi terhadap kemampuan memecahkan problem matematika. Senada dengan penelitian Ni'am (2016) tentang pengaruh pengajaran strategi metakognitif terhadap kemampuan pemecahan masalah matematika pada siswa kelas 5 SD. Hasil penelitian ini menemukan bahwa tidak ada perbedaan kemampuan pemecahan masalah matematika antara siswa kelas 5 SD yang mendapatkan pengajaran strategi metakognitif dengan siswa yang tidak mendapatkan pengajaran strategi metakognitif. Berbeda dengan penelitian Prabawanto (2018) dan Alfurofika, Waluya, dan Supartono (2013) tentang pengaruh model pembelajaran kooperatif (cooperative learning) dengan strategi metakognitif terhadap self-efficacy pemecahan masalah matematika pada mahasiswa jurusan pendidikan dan pada siswa kelas VII. Kedua penelitian ini menunjukkan adanya peningkatan self-efficacy pemecahan masalah matematika pada subjek setelah mendapatkan intervensi strategi metakognitif.

Berdasarkan latar belakang dan penelitian terdahulu, peneliti bermaksud menerapkan pengajaran strategi metakognitif IDEA untuk meningkatkan self-efficacy siswa kelas 5 SD dalam bidang pemecahan soal cerita matematika.

Rumusan masalah dalam penelitian ini, yaitu apakah pengajaran strategi metakognitif IDEA berpengaruh terhadap peningkatan self-efficacy pemecahan soal cerita matematika pada siswa kelas 5 SD?

\section{METODE PENELITIAN}

\section{Partisipan}

Partisipan dalam penelitian ini adalah siswa kelas 5 Sekolah Dasar Swasta Nasional X, Jakarta Barat. Partisipan berusia antara 11 sampai dengan 12 tahun. Pada penelitian ini menggunakan teknik pengambilan sampel dengan cara purposive sampling, yaitu pengambilan subjek dengan menetapkan kriteria tertentu. Kriteria tersebut, antara lain a) subjek mendapatkan hasil evaluasi belajar matematika pada semester lalu $<65$; b) subjek mendapatkan nilai rata-rata ulangan harian bahasa Inggris > 70; c) subjek memiliki taraf kecerdasan umum yang tidak bermasalah (golongan I dan II berdasarkan tes CPM); d) subjek mendapatkan nilai < 60 pada hasil pengambilan data awal soal cerita matematika, dan e) subjek memiliki kategori self-efficacy rendah. Pengambilan sampel dilakukan terhadap 27 siswa dari kelas 5C dan didapatkan 6 siswa (5 siswa perempuan dan 1 laki-laki) yang memenuhi kriteria dalam penelitian ini.

\section{Desain Penelitian}

Metode penelitian yang digunakan adalah metode kuantitatif. Desain penelitian yang digunakan adalah quasi experiment, one group pretest-postest design. Pengukuran variabel self-efficacy pemecahan soal cerita matematika disusun berdasarkan teori Bandura (1997) yang terdiri dari 
tiga dimensi, yaitu level, generality, dan strength. Alat ukur ini disusun dalam bahasa Inggris disesuaikan dengan bahasa pengantar yang digunakan sekolah. Setelah dilakukan uji validitas isi, face validity, dan uji realibilitas, dari 30 butir yang disusun didapatkan 22 butir valid dan reliabel. Adapun diperoleh nilai Cronbach Alpha sebesar 0.75 pada dimensi level, nilai Cronbach Alpha sebesar 0.776 pada dimensi generality, dan nilai Cronbach Alpha sebesar 0.747 pada dimensi strength.

Tabel 1. Contoh Butir Pernyataan Self-efficacy Pemecahan Soal Cerita Matematika

\begin{tabular}{|c|c|c|}
\hline Dimensi & Indikator & Butir Pernyataan dan Nomor Urut \\
\hline Level & $\begin{array}{l}\text { Memiliki keyakinan mampu } \\
\text { mengerjakan tugas yang sulit. }\end{array}$ & $\begin{array}{l}\text { (a) I am sure I can do difficult math word problems } \\
\text { on my homework ( } 3 \text {, butir positif). } \\
\text { (b) I can only do simple math word problems ( } 5 \text {, } \\
\text { butir negatif). }\end{array}$ \\
\hline Generality & $\begin{array}{l}\text { Memiliki keyakinan mampu melakukan } \\
\text { aktivitas dalam berbagai situasi (yang } \\
\text { biasa dilakukan dan yang tidak biasa } \\
\text { dilakukan). }\end{array}$ & $\begin{array}{l}\text { (a) I am sure I can do math word problems test that } \\
\text { given suddenly }(9 \text {, butir positif). } \\
\text { (b) I am not sure I can solve math word problems in } \\
\text { a limited time (14, butir negatif). }\end{array}$ \\
\hline Strength & $\begin{array}{l}\text { Memiliki keyakinan untuk bertahan } \\
\text { dalam menyelesaikan tugas hingga } \\
\text { selesai. }\end{array}$ & $\begin{array}{l}\text { (a) I believe I can complete all of my math word } \\
\text { problems exam (15, butir positif). } \\
\text { (b) I give up to finish math word problems (17, butir } \\
\text { negatif). }\end{array}$ \\
\hline
\end{tabular}

Penelitian ini diawali dengan proses pengambilan data menggunakan kuesioner self-efficacy dan mendapatkan 6 siswa berkategori self-efficacy rendah. Peneliti kemudian membuat rancangan intervensi yang dituangkan dalam sebuah modul. Modul yang dibuat berisi rancangan program intervensi berupa pengajaran strategi metakognitif I-D-E-A on Math Word Problem (Polya, 1973). Jenis penelitian ini termasuk penelitian kuasi eksperimen, sehingga proses intervensi dilakukan selama jam pelajaran matematika berlangsung. Enam partisipan akan mengikuti intervensi selama 2 minggu berturut-turut, bersama dengan 21 siswa lainnya. Keenam partisipan diposisikan duduk pada barisan depan selama intervensi berlangsung. Intervensi dilakukan selama 8 sesi dengan durasi 70 menit per sesi. Keenam partisipan selalu hadir pada seluruh pelaksanaan sesi intervensi.

Pelaksanaan sesi intervensi selalu diawali dengan permainan pada setiap sesi untuk mencairkan suasana dan membangun ketertarikan siswa belajar matematika. Pada akhir sesi peneliti selalu melakukan evaluasi bersama partisipan, yaitu meminta partisipan untuk bertanya kembali mengenai hal yang belum dimengerti. Pengajaran dengan strategi metakognitif IDEA diaplikasikan dalam topik pembahasan soal cerita matematika mengenai bab Kecepatan (Rate).

Pada sesi pertama, peneliti memberikan pemaparan mengenai strategi metakognitif IDEA on Math Word Problem melalui pemutaran video. Strategi metakognitif IDEA terdiri dari empat langkah, yaitu mengidentifikasi dan memahami masalah (identify the problem), membuat rencana perhitungan (develop a solution), melakukan perhitungan (evaluation), dan melakukan pengecekan kembali (assess your answer). Setelah pemaparan video, peneliti menjelaskan kembali di papan tulis dan memberikan kesempatan kepada partisipan untuk bertanya. Pada sesi kedua, peneliti menjelaskan mengenai penerapan strategi metakognitif IDEA pada soal cerita mengenai kecepatan dengan tingkat kesulitan rendah. Kemudian, sesi dilanjutkan dengan mengerjakan soal pada lembar kerja siswa menggunakan dua langkah, yaitu mengidentifikasi masalah dan membuat rencana perhitungan. Sesi ketiga dilakukan dengan memberikan kuis terkait materi yang telah dijelaskan pada sesi kedua. Kuis dikerjakan menggunakan empat langkah strategi metakognitif IDEA. Sesi keempat, peneliti melanjutkan materi dengan 
memberikan pengajaran soal cerita mengenai kecepatan dengan tingkat kesulitan lebih tinggi. Sesi kelima, partisipan dijelaskan materi soal cerita mengenai kecepatan yang disajikan dalam bentuk tabel. Peneliti kemudian memberikan tugas terkait kepada partisipan untuk dikerjakan di rumah. Pada sesi keenam, partisipan mengumpulkan tugas yang diberikan kemudian dilanjutkan dengan diskusi materi soal cerita mengenai kecepatan yang disajikan dalam bentuk grafik. Sebelum sesi keenam berakhir, peneliti memberikan lembar monitoring belajar kepada partisipan dan meminta mereka melengkapi pertanyaan yang diberikan. Sesi ketujuh, yaitu membahas materi soal cerita mengenai kecepatan debit air yang mengalir keluar atau masuk dalam sebuah wadah. Pada sesi delapan peneliti melakukan evaluasi materi dengan tujuan untuk mengetahui penguasaan pemahaman partisipan dalam mengerjakan soal cerita pada topik pembahasan Kecepatan. Peneliti memberikan empat buah soal dan meminta partisipan mengerjakan dengan empat langkah strategi metakognitif IDEA. Setelah menyelesaikan soal, partisipan diminta untuk menuliskan pengalaman mereka pada lembar evaluasi belajar siswa.

\section{HASIL DAN PEMBAHASAN}

Uji normalitas dengan uji one sample $K$-S pada alat ukur self-efficacy menunjukkan bahwa data terdistribusi normal (pre-test $\rho=0.747>0.05$; post-test $\rho=0.632>0.05$ ). Dari hasil perhitungan uji beda, diperoleh nilai mean self-efficacy sebelum dan sesudah intervensi pengajaran strategi metakognitif sebesar 53.33 ( $\mathrm{SD}=3.50$ ) dan 63.00 ( $\mathrm{SD}=14.11)$, yang artinya tidak ada perbedaan signifikan pada self-efficacy sebelum dan sesudah intervensi pengajaran strategi metakognitif $(\mathrm{t}=-1.535, \rho=0.185>0.05)$. Hasil uji beda dapat dilihat pada tabel 2 .

Tabel 2. Uji Beda Self-efficacy Sebelum dan Sesudah Intervensi Pengajaran Strategi Metakognitif

\begin{tabular}{lccc}
\hline \multirow{2}{*}{ Self-efficacy } & \multicolumn{2}{c}{ Hasil Data } \\
\cline { 2 - 4 } & $\begin{array}{c}\text { Sebelum } \\
\text { Intervensi }\end{array}$ & $\begin{array}{c}\text { Sesudah } \\
\text { Intervensi }\end{array}$ & $\begin{array}{c}\text { Paired Sample T-Test } \\
\text { (Sebelum dan Sesudah) }\end{array}$ \\
\hline Jumlah Partisipan (N) & 6 & 6 & 6 \\
Mean $(M)$ & 53.33 & 63.00 & -9.67 \\
Standard Deviation (SD) & 3.50 & 14.11 & 15.42 \\
Nilai t & & & -1.53 \\
Df & & & 5 \\
Sig. (2-tailed) & & $\mathbf{0 . 1 8 5}$ \\
\hline
\end{tabular}

Belum adanya pengaruh pengajaran strategi metakognitif terhadap self-efficacy pemecahan soal cerita matematika dapat ditinjau melalui proses intervensi. Dalam penelitian ini faktor-faktor yang memengaruhi self-efficacy yang secara teoretis dapat dikondisikan saat intervensi, tidak tercipta dengan baik. Britner \& Pajares (dalam Katz, 2015) mengatakan bahwa mastery experience adalah prediktor signifikan dari self-efficacy. Pada proses intervensi, beberapa kali peneliti memberikan pertanyaan kepada partisipan tentang topik yang sedang dibahas. Namun, dari keenam partisipan hanya subjek FF dan AS yang berusaha inisiatif memberikan jawaban, subjek lain cenderung menunggu giliran ditunjuk. Sementara itu, disebabkan desain penelitian kuasi eksperimen (pengajaran digabung dengan siswa lain dalam ruang yang sama) semakin memperkecil peluang partisipan menjawab pertanyaan dari peneliti. Dengan demikian, kurangnya pengalaman keberhasilan (mastery experience) yang dialami partisipan menjadi salah sumber self-efficacy yang kurang terpenuhi.

Dari keenam partisipan, hanya satu partisipan yang mengalami penurunan skor total self-efficacy. Subjek FF menunjukkan peningkatan poin relatif tinggi sebesar 39, kemudian AS dan VN mengalami peningkatan sebesar 8 poin, AT meningkat sebesar 6 poin, $\mathrm{CH}$ meningkat sebesar 4 poin, sedangkan KE mengalami penurunan sebesar 7 poin. 
Data skor pre-test dan post-test self-efficacy dari keenam partisipan dapat dilihat pada tabel 3.

Tabel 3. Hasil Skor Pre-test dan Post-test Self-efficacy Partisipan

\begin{tabular}{ccccc}
\hline & & \multicolumn{2}{c}{ Self-Efficacy } & \\
\cline { 3 - 4 } No. & Inisial Subjek & Pre-test & Post-test & Gain score \\
\hline 1. & AS & 56 & 64 & 8 \\
2. & AT & 54 & 60 & 6 \\
3. & CH & 56 & 60 & 4 \\
4. & FF & 48 & 87 & 39 \\
5. & KE & 50 & 43 & -7 \\
6. & VN & 56 & 64 & 8 \\
\hline
\end{tabular}

Faktor lain yang memengaruhi tingkat self-efficacy, yaitu sifat dari tugas yang dihadapi individu (Bandura, 1986). Berdasarkan rekapitulasi dari lembar monitoring dan lembar evaluasi, subjek KE menyatakan kesulitan pada topik rate. Selain subjek KE, kelima subjek lainnya mengalami kesulitan pada subtopik tabel dan grafik. Tingkat kesulitan tugas juga berpengaruh bagi partisipan dalam menentukan tingkat self-efficacy. Semakin mampu individu mengerjakan tugas yang dianggapnya sulit, maka akan meningkatkan self-efficacy, semakin individu merasa kesulitan mengerjakan tugas yang dianggap sulit akan menurunkan self-efficacy (Bandura, 1986).

Meninjau kembali teori Bandura (1994), individu yang diyakinkan secara verbal cenderung akan berusaha lebih keras untuk mencapai suatu keberhasilan. Pemberian umpan balik pada saat sesi intervensi yang berfungsi sebagai verbal persuasion juga kurang dirasakan bagi partisipan. Hal ini disebabkan jumlah peserta intervensi sebanyak 27 siswa, sehingga peneliti kurang dapat memberikan perhatian secara penuh kepada enam partisipan. Pertanyaan yang diajukan kepada partisipan tidak dipandang sebagai verbal persuasion yang membantu dalam menyelesaikan soal cerita matematika. Tetapi, pertanyaan metakognitif membuat mereka cemas dan bingung, sehingga self-efficacy partisipan tidak mengalami peningkatan yang berarti. Selain itu, pertanyaan atau umpan balik yang diajukan pada umumnya dapat dijawab hanya oleh beberapa siswa yang dianggap pandai dalam kelas tersebut.

Selain faktor-faktor di atas, vicarious experience juga menjadi salah satu sumber self-efficacy. Pengamatan terhadap keberhasilan orang lain dengan kemampuan yang sebanding dalam mengerjakan suatu tugas akan meningkatkan self-efficacy individu dalam mengerjakan tugas yang sama (Bandura, 1994). Keterbatasan waktu dalam pelaksanaan intervensi, berdampak pada kurangnya kesempatan partisipan untuk berdiskusi dengan teman-temannya. Partisipan hanya mendapatkan contoh dari peneliti sebagai guru, sehingga pengalaman terhadap keberhasilan orang lain yang sebaya (vicarious experience) kurang dirasakan partisipan.

Berdasarkan analisis melalui observasi, lembar kerja partisipan, serta lembar rencana, monitoring, dan evaluasi belajar partisipan didapatkan bahwa partisipan mengalami kesulitan pada topik pembahasan yang dipersepsikan sulit bagi mereka, yaitu pada pembahasan tabel dan grafik. Hal ini dikonfirmasi dari nilai yang didapatkan partisipan pada lembar kerja D dan E cenderung rendah, serta tulisan partisipan pada lembar monitoring dan evaluasi yang menyatakan bahwa mereka masih merasa kesulitan pada bagian tabel dan grafik. Faktor tersebut juga menjadi salah satu penyebab siswa tidak memiliki keyakinan dalam mengerjakan soal yang diberikan. 


\section{KESIMPULAN DAN SARAN}

Berdasarkan penelitian yang telah dilakukan terhadap siswa kelas 5 SD X Jakarta Barat, dapat disimpulkan bahwa tidak ada pengaruh pengajaran strategi metakognitif terhadap peningkatan self-efficacy pemecahan soal cerita matematika. Hal ini berarti bahwa pengajaran strategi metakognitif belum mampu meningkatkan self-efficacy siswa dalam bidang pemecahan soal cerita matematika. Belum adanya pengaruh pengajaran strategi metakognitif terhadap selfefficacy pemecahan soal cerita matematika disebabkan adanya faktor-faktor yang belum terpenuhi pada partisipan. Faktor-faktor tersebut, antara lain mastery experience, vicarious experience, verbal persuasion yang belum terpenuhi sehingga partisipan tidak mengalami peningkatan self-efficacy.

Saran yang dapat diberikan untuk pengembangan praktis di sekolah antara lain, memberikan pendampingan belajar tambahan (enrichment program) bagi siswa yang bermasalah dalam selfefficacy siswa di bidang pemecahan masalah matematika dengan metode pengajaran yang relevan bagi kebutuhan siswa. Di samping itu, ada baiknya program remedial di sekolah diminimalisir dan difokuskan pada program monitoring serta evaluasi. Hal ini bertujuan agar usaha belajar siswa terfokuskan pada cara mencapai target dengan usaha maksimal, bukan pada cara mencapai hasil terbaik melalui remedial. Remedial menggambarkan keberhasilan yang tertunda yang dapat mengarahkan pada tertundanya individu memeroleh mastery experience, sehingga memengaruhi self-efficacy siswa dalam pencapaian prestasi.

Saran teoretis dari penelitian ini adalah adanya pengembangan alat ukur self-efficacy yang dapat digunakan secara lebih luas dan tidak terbatas pada bidang pemecahan masalah matematika saja. Selain itu, peneliti juga sangat mengharapkan adanya penelitian-penelitian selanjutnya yang dapat mengukur self-efficacy yang bebas budaya (culture fair).

\section{Ucapan Terima Kasih (Acknowledgement)}

Peneliti mengucapkan terima kasih kepada Sekolah Dasar X, Jakarta Barat yang telah mengizinkan dalam pengambilan data dan pelaksanaan program pengajaran. Peneliti juga mengucapkan terima kasih kepada semua partisipan yang bersedia mengikuti pelaksanaan intervensi dari awal hingga tuntas. Terima kasih juga kepada semua pihak yang tidak dapat peneliti sebutkan satu per satu, sehingga penelitian ini dapat terlaksana tepat waktu.

\section{REFERENSI}

Akin, A., \& Kurbanoglu, I. N. (2011). The relationships between math anxiety, math attitudes, and self-efficacy: A structural equation model. Studia Psychologica, 53(3), 263-273.

Alfurofika, P. S., Waluya, B. S., \& Supartono. (2013). Model pembelajaran jigsaw dengan strategi metakognitif untuk meningkatkan self-efficacy dan kemampuan pemecahan masalah. Unnes Journal of Mathematics Education Research, 2(2), 128-133.

Bandura, A. (1986). Social foundations of thought and action: A social cognitive theory. Englewood Cliffs, NJ: Prentice Hall.

Bandura, A. (1994). Self-efficacy. In V. S. Ramachaudran (Ed.), Encyclopedia of human behavior, 4, 71-81. New York: Academic Press.

Bandura, A. (1997). Self-efficacy: The exercise of control. New York: W. H. Freeman.

Cahyani, B. H. (2008). Efektivitas pelatihan regulasi metakognisi untuk meningkatkan kemampuan memecahkan problem matematika [Tesis tidak dipublikasikan]. Universitas Gadjah Mada, Yogyakarta.

Cornoldi, C., Carretti, B., Drusi, S., \& Tencati, C. (2015). Improving problem solving in primary school students: The effect of a training programme focusing on metacognition and 
working memory. British Journal of Educational Psychology, 85, 424-439. doi:10.1111/bjep.12083

Coutinho, S. A., \& Neuman, G. (2008). A model of metacognition, achievement goal orientation, learning style and self-efficacy. Learning Environments Research, 11, 131-151. doi: 10.1007/s10984-008-9042-7

García, T., Rodríguez, C., Castro, P. G., Pienda, J. A. G., \& Torrance, M. (2016). Elementary students' metacognitive processes and post-performance calibration on mathematical problem-solving tasks. Metacognition Learning, 11, 139-170. doi: 10.1007/s11409-0159139-1

Gurat, M., G., \& Medula, Jr., C., T. (2016). Metacognitive strategy knowledge use through mathematical problem solving amongst pre-service teachers. American Journal of Educational Research, 4(2), 170-189. doi:10.12691/education-4-2-5

Hepler, T. J., \& Feltz, D. L. (2012). Path analysis examining self-efficacy and decision-making performance on a simulated baseball task. Research Quarterly for Exercise and Sport, 83(1), 55-64.

Hoffman, B., \& Spatariu, A. (2008). The influence of self-efficacy and metacognitive prompting on math problem-solving efficiency. Contemporary Educational Psychology, 33, 875-893. doi: 10.1016/j.cedpsych.2007.07.002

Iswadi, H. (2016, Desember 7). Sekelumit dari hasil PISA 2015 yang baru dirilis. http://www.ubaya.ac.id/2014/content/articles_detail/230/Sekelumit-Dari-Hasil-PISA 2015Yang-Baru-Dirilis.html

Jameson, M. M., \& Fusco, B. R. (2014). Math anxiety, math self-concept, and math self-efficacy in adult learners compared to traditional undergraduate students. Adult Education Quarterly, 64(4), 306-322. doi: 10.1177/0741713614541461

Katz, S. (2015). Enhancing self-efficacy of elementary school students to learn mathematics. Journal of Curriculum and Teaching, 4(1), 42-55. doi:10.5430/jct.v4n1p42

Kemendikbud. (2013). Kompetensi dasar sekolah dasar / madrasah ibtidaiyah. Jakarta. pendidikan-diy.go.id/file/mendikbud/kurkiulum-2013-kompetensi-dasar

Kramarski, B., Mevarech, Z. R., \& Arami, M. (2002). The effects of metacognitive instruction on solving mathematical authentic tasks. Educational Studies in Mathematics, 49, 225-250.

Kvedere, L. (2014). Mathematics self-efficacy, self-concept and anxiety among $9^{\text {th }}$ grade students in latvia. Procedia-Social and Behavioral Sciences, 116, 2687-2690. doi: 10.1016/j.sbspro.2014.01.636

Lai, Y., Zhu, X., Chen, Y., \& Li, Y. (2015). Effects of mathematics anxiety and mathematical metacognition on word problem solving in children with and without mathematical learning difficulties. Plos One, 10(6), 1-19. doi:10.1371/journal.pone.0130570

Lopez, F. G, \& Lent, R. W. (1992). Career self-efficacy: Sources of mathematics self-efficacy in high school students. The Career Development Quarterly, 41, 3-12.

Montague, M. (2008). Self-regulation strategies to improve mathematical problem solving for students with learning disabilities. Learning Disability Quarterly, 31, 37-44.

Nelson, L.L. (2012). The effectiveness of metacognitive strategies on 8th grade students in mathematical achievements and problem solving skills [Unpublished doctoral thesis]. The Graduate School Southern University and A \& M College Baton Rouge, Louisiana.

Ni'am, M. M. (2016). Pengaruh pengajaran strategi metakognitif terhadap kemampuan pemecahan masalah matematika dan perubahan gelombang otak [Tesis tidak dipublikasikan]. Universitas Gadjah Mada, Yogyakarta.

Nurfuadah, R. N. (2013, Januari 8). Penyebab indeks matematika siswa RI terendah di dunia. Okezone. $\quad$ http://kampus.okezone.com/read/2013/01/08/373/743021/penyebabindeksmatematika siswa-ri-terendah-di-dunia/large 
Ozsoy, G., \& Ataman, A. (2009). The effect of metacognitive strategy training on mathematical problem solving achievement. International Electronic Journal of Elementary Education, 1(2), 68-83.

Pajares, F., \& Miller, M. D. (1994). Role of self-efficacy and self-concept beliefs in mathematical problem solving: A path analysis. Journal of Educational Psychology, 86(2), 193-203.

Pajares, F. (2005). Gender differences in mathematics self-efficacy beliefs. In A. Gallagher \& J. Kaufman (Eds.), Mind Gap: Gender Differences in Mathematics, 294-315. Boston: Cambridge University Press.

Pajares, F. (2008). Motivational role of self-efficacy beliefs in self-regulated learning. In D. H. Schunk \& B. J. Zimmerman (Eds.), Motivation and self-regulated learning: Theory, research and applications, 111-139. New York: Lawrence Erlbaum Associates.

Paulsen, A. M., \& Betz, N. E. (2004). Basic confidence predictors of career decision-making self-efficacy. The Career Development Quarterly, 52, 354-362.

Pennequin, V., Sorel, O., Nanty, I., \& Fontaine, R. (2010). Metacognition and low achievement in mathematics: The effect of training in the use of metacognitive skills to solve mathematical word problems. Thinking \& Reasoning, 16(3), 198-220. doi: $10.1080 / 13546783.2010 .509052$

Polya, G. (1973). How to solve it ( $2^{\text {nd }}$ Ed.) New Jersey: Princeton University Press.

Prabawanto, S. (2018). The enhancement of students' mathematical self-efficacy through teaching with metacognitive scaffolding approach. Journal of Physics: Conf. Ser., 1013, 17. doi :10.1088/1742-6596/1013/1/012135

Putwain, D. W., \& Symes, W. (2014). The perceived value of maths and academic self-efficacy in the appraisal of fear appeals used prior to a high-stakes test as threatening or challenging. Social Psychology of Education, 17, 229-248. doi: 10.1007/s11218-014-92497

Satria. (2012, Februari 24). Mutu pendidikan matematika di indonesia masih rendah. Liputan/Berita. http://ugm.ac.id/id/post/page?id=4467

Schunk, D. H., \& Rice, J. M. (1991). Learning goals and progress feedback during reading comprehension instruction. Journal of Reading Behavior, 23, 351-364.

Schunk, D. H., \& Ertmer, P. A. (2000). Self-regulation and academic learning: Self-efficacy enhancing interventions. In M. Boekaerts, P. R. Pintrich, \& M. Zeidner (Eds.), Handbook of self-regulation, 631-649. San Diego, CA: Academic Press.

Tajika, H., Nakatsu, N., Nozaki, H., Neumann, E., \& Maruno, S. (2007). Effects of selfexplanation as a metacognitive strategy for solving mathematical word problem. Japanese Psychological Research, 49, 222-233. doi: 10.1111./j.1468-5884.2007.00349.x.

Teong, S. (2003). The effect of metacognitive training on mathematical word problem solving. Journal of Computer Assisted Learning, 19, 46-55. doi: 10.1046/j.0266-4909.2003.00005.x

Zimmerman, B. J. (2002). Becoming a self-regulated learner: An overview. Theory into Practice, $41,64-70$.

Zimmerman, B. J. (2002). Achieving self-regulation: The trial and triumph of adolescence. In F. Pajares \& T. Urdan (Eds.), Academic Motivation of Adolescents, 2, 1-27. Greenwich, CT: Information Age. 